\title{
Does preoperative iodide treatment for thyrotoxicosis bring about involution?
}

\author{
T. J. WILKIN, J. SWANSON BECK ${ }^{1}$, AND W. MICHIE \\ From the Departments of Therapeutics and Pathology, University of Dundee, and Aberdeen \\ Royal Infimary
}

SUMMARY It is generally believed that preoperative iodide decreases the hyperplasia of the toxic thyroid gland. Histometric studies of glands from thyrotoxic patients pretreated with propranolol alone compared with those from patients pretreated with propranolol and iodide failed to confirm this. Although histological appearances and volume percentage measurement of component tissues suggested that the glandular epithelium had involuted after iodine treatment, measurement of their absolute mass indicated that the mean mass of epithelium was the same in both groups and that involution had not occurred. We conclude that considerable confusion in the thyroid literature has arisen through incorrect use of the term involution.

The histology of the untreated thyrotoxic gland has been well documented (Marine and Lenhart, 1911; Wegelin, 1926) but is now rarely seen. Iodide is widely believed to induce involution by reducing the hyperplasia (Green, 1971; Meissner, 1971; Ingbar and Woeber, 1974) and vascularity (Rienhoff, 1925) of the toxic gland, and several authors have used the fall in epithelial cell height as a measure of involution (Rawson and McArthur, 1947; Sommers, 1968). Properly defined, involution means the shrinkage of an organ towards its original size (Butterworth's Medical Dictionary, 1965) and implies a reduction in cellular content (Dorland's Medical Dictionary, 1974).

Thyroid stimulating immunoglobulins (TSI) have been found in all patients with untreated Graves' disease, and this antibody is strongly implicated as a cause of the hyperthyroidism (Mukhtar et al., 1975). The half-life of TSI is presumably the same as that of IgG (15-20 days) and it seems improbable that TSI levels could be influenced by a 10 -day preoperative course of iodide. It is therefore pertinent to question whether involution of thyroid tissues can occur at a time when TSI stimulation persists. The purpose of this investigation is to test the hypothesis that iodide induces involution by determining histometrically whether the size and cellular content of thyroids from

'Correspondence: Professor J. Swanson Beck, Department of Pathology, Ninewells Hospital and Medical School, Dundee, DD2 IUB.

Received for publication 15 June 1976 thyrotoxic patients treated with propranolol and iodide differs from that of patients treated with propranolol alone.

\section{Patients and methods}

Two groups of patients were studied. The first (group 1) received propranolol, $160 \mathrm{mg}$ daily, for periods of up to six weeks before undergoing subtotal thyroidectomy, and the second (group 2) received 20 minims of Lugol's iodine (iodine with potassium iodide) thrice daily for the 10 days immediately before operation in addition to a similar course of propranolol. The patients were not selected and were drawn from two successive 18-month periods during which iodide was first included and then omitted from the preoperative régime. Group 1 comprised 38 patients, mean age 34.2 years, of whom 7 were male and 31 female. The mean age of the 32 patients in group 2 was 32.6 years; 5 were male and 27 female. There was no statistically significant difference in the age and sex distribution between the two groups.

A standard thyroidectomy was used throughout. Total gland mass was calculated from the weight of the resected specimen plus the estimated remnant. The errors involved in estimating the remnant mass are known to be small relative to the total gland mass (Hedley et al.. 1972). Both diffusely toxic glands and multinodular toxic goitres were included in the study.

Histometric measurement of each specimen was 
made to assess the volume percentage and absolute mass of each of the tissue elements. The volume percentage of individual tissues was determined by a point-counting technique previously described (Young et al., 1975) and the mass of each was calculated from the product of its volume percentage and the total mass of the gland. The scalloped retraction spaces at the acinar margins of the colloid are fixation artefacts which are not present in life (Haley $e t$ $a l ., 1955)$. Such spaces were counted along with stained colloid. To avoid bias in selecting areas for point-counting, particularly in nodular goitres, fields were chosen by computer-generated pseudorandom numbers which determined the coordinates of the microscope stage.

\section{Results}

Mean total gland mass was $38.3 \mathrm{~g}$ in group 1 and $52 \cdot 6 \mathrm{~g}$ in group 2 .

\section{HISTOLOGY}

In many of the patients from group 1 the appearances were consistent with classical descriptions of untreated thyrotoxicosis, while those of group 2 showed characteristics of involution. Although there was wide variation within each group, the overall impression was that the glands from patients pretreated with propranolol and iodide contained more colloid and less epithelium than those from patients prepared with propranolol alone. The acinar epithelium in the former group tended to be flat in contrast to the columnar appearance in glands pretreated with propranolol alone.

\section{HISTOMETRY}

The volume percentage of all tissues showed a wide scatter in both groups with significantly less epithelium and more colloid in the iodide-treated glands (Table 1). In contrast, measurement of the tissues by mass revealed no such difference in epithelium between the two groups (Table 2). The iodised glands contained almost twice the mass of colloid as those in group 1 , and this accounted for much of the difference in mean total gland mass between the groups. That portion of the difference in total gland mass not accounted for by colloid might be ascribed to the greater mass of stroma in the iodised glands although neither this difference nor that in lymphocyte content between the groups reached significant levels. (Since the lymphoid tissue in thyrotoxic glands is not 'normally' distributed, the Wilcoxon test for non-parametric statistics was used when comparing the amounts of lymphoid tissue in the two groups.)
Table 1 Mean volume percentage of component tissues in thyroids from patients with thyrotoxicosis following preoperative preparation with propranolol alone (group 1) and propranolol plus iodide (group 2)

\begin{tabular}{|c|c|c|c|c|}
\hline \multirow{2}{*}{$\begin{array}{l}\text { Treatment } \\
\text { group }\end{array}$} & \multicolumn{4}{|c|}{ Mean volume percentage $\pm S D$} \\
\hline & Colloid & Epithelium & Stroma & $\begin{array}{l}\text { Lymphoid } \\
\text { tissue }\end{array}$ \\
\hline $\begin{array}{l}1 \\
2 \\
\text { Statistical } \\
\text { Significance }\end{array}$ & $\begin{array}{l}31.1 \pm 15.1 \\
38.5 \pm 16.9 \\
t=1.93 \\
P<0.05\end{array}$ & $\begin{array}{l}42.1 \pm 14.1 \\
33.8 \pm 13.8 \\
t=2.47 \\
P<0.01\end{array}$ & $\begin{array}{l}23 \cdot 6 \pm 7 \cdot 3 \\
25 \cdot 0 \pm 7 \cdot 3 \\
t=0 \cdot 80 \\
N S\end{array}$ & $\begin{array}{l}2 \cdot 2 \pm 2 \cdot 2 \\
2 \cdot 2 \pm 2 \cdot 9 \\
x_{1}{ }^{1}=-0.06 \\
N S\end{array}$ \\
\hline
\end{tabular}

${ }^{1} \chi_{1}$ Statistic in Wilcoxon test. NS $=$ not significant at $5 \%$ level.

Table 2 Mean mass of component tissues in thyroids from patients with thyrotoxicosis following preoperative preparation with propranolol alone (group 1) and propranolol plus iodide (group 2)

\begin{tabular}{|c|c|c|c|c|c|}
\hline \multirow{2}{*}{$\begin{array}{l}\text { Treatment } \\
\text { group }\end{array}$} & \multicolumn{5}{|c|}{ Mean mass $(g) \pm S D$} \\
\hline & Colloid & Epithelium & Stroma & $\begin{array}{l}\text { Lymphoid } \\
\text { tissue }\end{array}$ & $\begin{array}{l}\text { Total } \\
\text { gland mass }\end{array}$ \\
\hline $\begin{array}{l}1 \\
2 \\
\text { Statistical } \\
\text { significance }\end{array}$ & $\begin{array}{l}11 \cdot 3 \pm 7.4 \\
21 \cdot 3 \pm 29.6 \\
t=2.04 \\
P<0.025\end{array}$ & $\begin{array}{l}16 \cdot 8 \pm 11 \cdot 0 \\
16 \cdot 5 \pm 12 \cdot 0 \\
t=0 \cdot 12 \\
N S\end{array}$ & $\begin{array}{l}9 \cdot 5 \pm 6 \cdot 6 \\
14 \cdot 1 \pm 3 \cdot 7 \\
t=1 \cdot 26 \\
\text { NS }\end{array}$ & $\begin{array}{l}0.85 \pm 1 \cdot 1 \\
0.97 \pm 1 \cdot 2 \\
x_{1}^{1}= \\
-0.09 \\
\text { NS }\end{array}$ & $\begin{array}{l}38 \cdot 3 \pm 18 \cdot 5 \\
52 \cdot 6 \pm 58 \cdot 7\end{array}$ \\
\hline
\end{tabular}

${ }^{2} \chi_{1}$ Statistic in Wilcoxon test. NS $=$ not significant at $5 \%$ level.

\section{Discussion}

Pharmacological doses of iodide are frequently used in the preparation of patients for thyroidectomy because the gland is said to be firmer and to bleed less at the time of operation (Rienhoff, 1925). In addition, it is claimed that iodide brings about involution of the hyperplastic gland (Green, 1971). Propranolol does not appear to influence the function of the toxic thyroid gland (Hadden et al., 1969) and is therefore unlikely itself to modify thyroid histology. While the fall in volume percentage of epithelium supports the histological impression that iodide reduces toxic hyperplasia, the results indicate that the mass of epithelium in fact remains the same irrespective of medication.

Why does the histologist gain a false impression of involution? Figure 1 shows two histological sections reported as 'normal'. Section A, however, comes from a gland weighing $142 \mathrm{~g}$ and containing $48 \mathrm{~g}$ of epithelium while section $B$ is taken from a gland weighing $14 \mathrm{~g}$ which contained only $4.6 \mathrm{~g}$ of epithelium. In either case the volume percentage is similar (34\% and $33 \%$ respectively) but whereas an epithelial content of $4.6 \mathrm{~g}$ is normal, that of $48 \mathrm{~g}$ indicates extreme hyperplasia. Conversely, histo- 


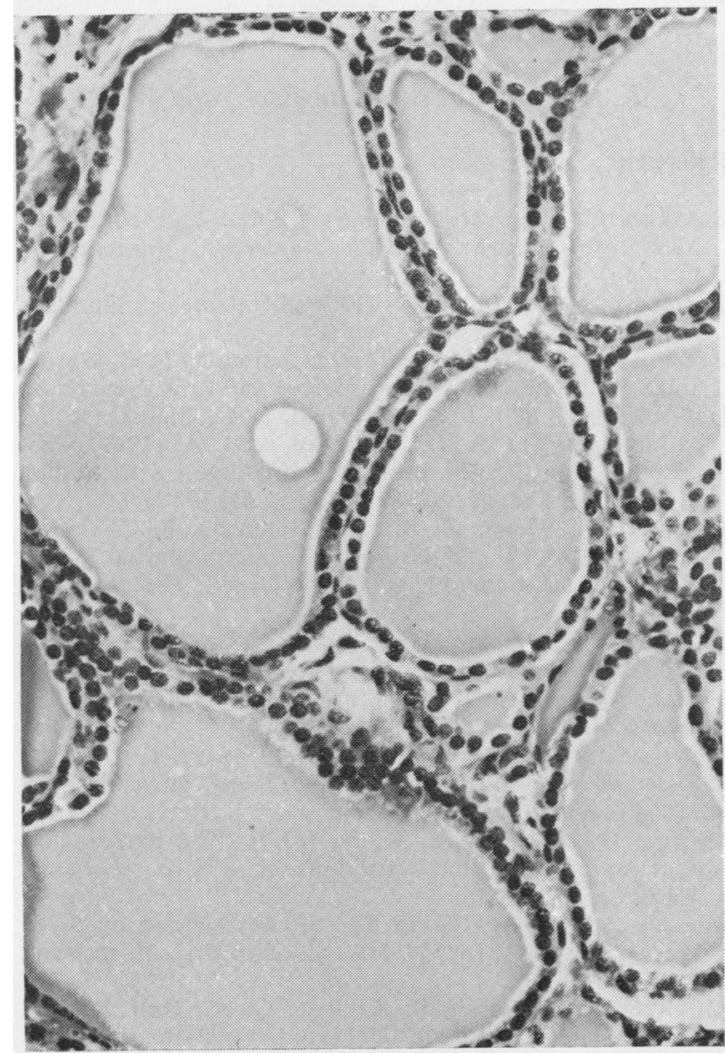

Fig 1a

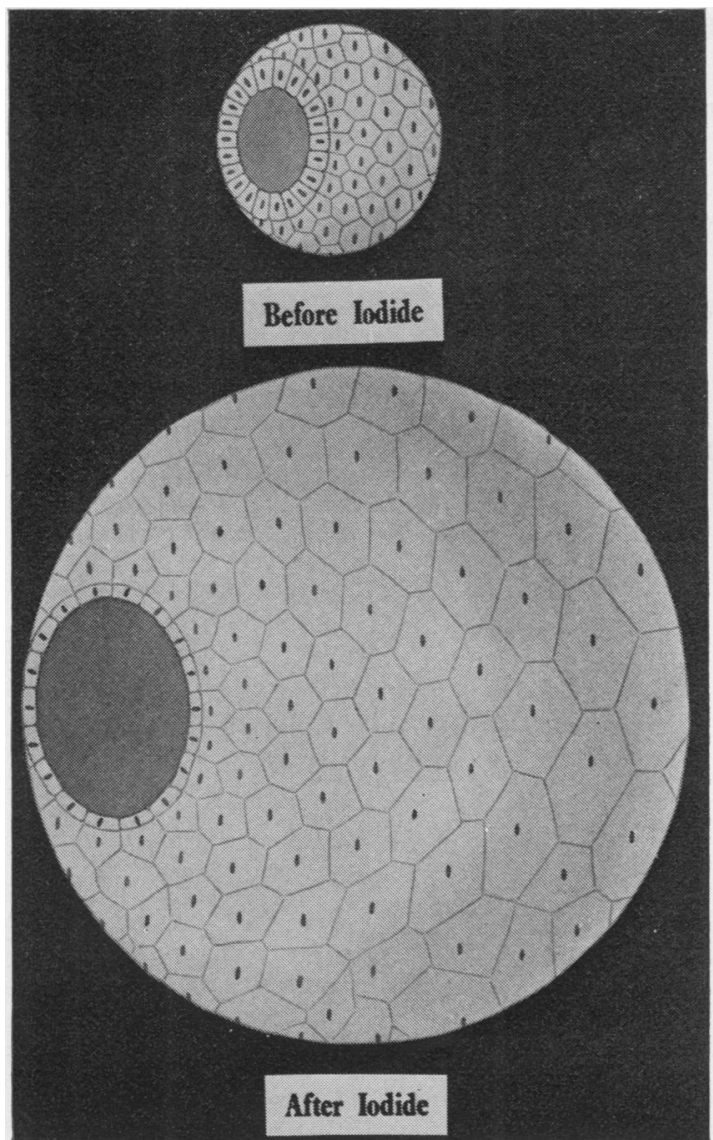

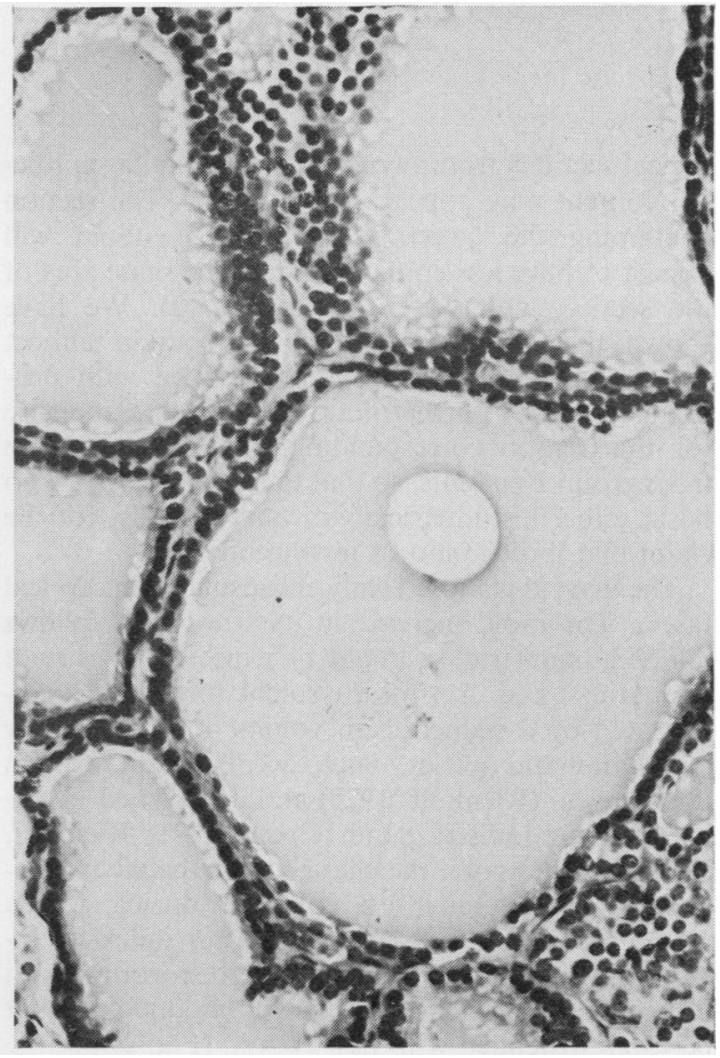

Fig 1b

Fig. 1 Histologically similar sections from two very different thyroid glands. Section A was taken from a severely hyperplastic gland the epithelial content of which was 10 times greater than that from which section $B$ was cut.

Fig. 2 Diagram to explain how distension of the toxic thyroid follicle during iodide administration might account for the false impression of involution obtained histologically. The epithelial mass remains unchanged. 
logical sections from two glands with similar epithelial content may appear very different. The section containing the larger percentage of colloid will appear to have less epithelium than the same area of the section with little colloid (Fig. 2). We have shown that iodide-treated glands contain almost twice as much colloid as those treated with propranolol alone. Furthermore, the iodised glands are for this reason correspondingly larger than those from group 1 patients, so that there appears to be no basis, either histometrically or anatomically, for the claim that iodide induces involution.

The thyroid gland is firmly encapsulated in cervical fascia. The rapid increase in its size which follows iodide administration might be expected to cause a temporary rise in intrathyroidal pressure, compensated by a reduction in volume of the vascular and lymphatic spaces. Such events might explain the firmness (Rienhoff, 1925) and diminished vascularity of the iodised gland (Green, 1971; Rienhoff, 1925). Furthermore, the change in epithelial appearance from columnar to cuboidal during iodide administration is less likely to be an index of involution than an expression of the distortion which cells lining the follicle must inevitably undergo as it becomes distended with new colloid (Fig. 2).

We conclude that considerable confusion in the thyroid literature has resulted in the past from incorrect use of the term involution which should be reserved for situations where an enlarged organ reverts towards its normal size by reduction in its cell mass (eg, postpartum uterus and postlactation breast). Attempts to correlate thyroid status with histological appearances are commonly made, and we believe that the present work casts considerable doubt upon their validity.

We thank Professor A. L. Stalker for access to histological sections prepared in the Department of Pathology, University of Aberdeen. This work was supported by a grant to JSB from the Scottish Hospitals Endowment Research Trust.

\section{References}

Butterworth's Medical Dictionary (1965). 2nd edition of $\overline{\vec{F}}$ McNalty's British Medical Dictionary. Butterworth, London.

Dorland's Medical Dictionary (1974). 25th edition. Saunders, Philadelphia.

Green, W. L. (1971). In The Thyroid, edited by S. C. Werner and S. H. Ingbar, 3rd edition. Harper and Row, New York.

Hadden, D. R., Bell, T. K., McDevitt, D. G., Shanks, R. G., Montgomery, D. A. D., and Weaver, J. A. (1969). Propranolol and the utilization of radioiodine by the human thyroid gland. Acta Endrocrinologica, 61, 393-399.

Haley, H. L., Dews, G. M., and Sommers, S. C. (1955). A histochemical comparison of primary thyroid hyperplasia and adenomatous goiter. Archives of Pathology, 59, 635-640.

Hedley, A. J., Michie, W., Duncan, T., Hems, G., and Crooks, J. (1972). The effect of remnant size on the outcome of subtotal thyroidectomy for thyrotoxicosis. British Journal of Surgery, 59, 559-563.

Ingbar, S. H. and Woeber, K. A. (1974). In Textbook of Endocrinology, edited by R. H. Williams, 5th edition, p. 121. Saunders, Philadelphia.

Marine, D. and Lenhart, C. H. (1911). The pathological anatomy of the human thyroid gland. Archives of Internal Medicine, 7, 506-535.

Meissner, W. A. (1971). In The Thyroid, edited by S. C. Werner and S. H. Ingbar, 3rd edition, p. 349. Harper and Row, New York.

Mukhtar, E. D., Smith, B. R., Pyle, G. A., Hall, R., and Vice, P. (1975). Relation of thyroid-stimulating immunoglobulins to thyroid function and effects of surgery, radioiodine, and antithyroid drugs. Lancet, 1, 713-715.

Rawson, R. W. and McArthur, J. W. (1947). What has thiouracil taught us about the pathologic physiology of Graves' disease? Western Journal of Surgery, 55, 27-38.

Rienhoff, W. F., Jr. (1925). The histological changes brought about in cases of exophthalmic goitre by the administration of iodine. Bulletin of the Johns Hopkins Hospital, 37, 285-306.

Sommers, S. C. (1968). In Endocrine Pathology, edited by J. M. B. Bloodworth, Jr., p. 147. Williams and Wilkins, Baltimore.

Wegelin, C. (1926). Die Struma basedowiana. In Drüsen mit innerer Sekretion (Handbuch der speziellen pathologischen Anatomie und Histologie, edited by F. Henke and O. Lubarsch, Band VIII), pp. 369-379. Springer, Berlin.

Young, R. J., Beck, J. S., and Michie, W. (1975). The predictive value of histometry of thyroid tissue in anticipating hypothyroidism after subtotal thyroidectomy for primary thyrotoxicosis. Journal of Clinical Pathology, 28, 94-98. 